\title{
Experimental fracture resistance study for cracked bovine femur bone samples
}

\author{
M.R.M. Aliha \\ Welding and Joining Research Center, School of Industrial Engineering, Iran University of Science and Technology (IUST), \\ Narmak, 16486-13114, Tebran, Iran \\ mrm_aliha@iust.ac.ir, https://orcid.org/0000-0001-9451-0949

\section{Hussein Ghazi} \\ Department of Biomedical Engineering, Science and Research Branch, Islamic Azad University, Tehran, Iran.

\section{Farkhondeh Ataei} \\ School of Progress Engineering, Iran University of Science and Technology (IUST), Narmak, 16486-13114, Tebran, Iran
}

\begin{abstract}
Crack growth and brittle fracture is one of the major failure modes in bone materials and therefore understanding the fracture behavior and affecting parameters on the crack growth resistance of bone is necessary for biomechanics researchers. In this paper, mode I fracture toughness value for the left and right femur bones of same bovine were measured experimentally using several single edge notch bend beam specimens (SENB) subjected to three-point bend loading in dry condition. The SENB specimens were cut along the longitudinal axis of bone but from different hoop directions. Fracture toughness results of sample prepared from the frontal part of bone were higher than the back or side sections. Depending on the location of sample, the fracture toughness of femur bone was varied from 5 to $10 \mathrm{MPa} \sqrt{\mathrm{m}}$. Furthermore, the results obtained for similar location of both left and right femur bones were nearly identical. The fracture energy $\left(G_{\mathrm{f}}\right)$ of the tested specimens was also measured and it was found that a linear relation can be fitted to the $\left(K_{\mathrm{Ic}}\right)^{2}$ versus $G_{\mathrm{f}}$ results of the tested bovine bone.
\end{abstract}

KEYwORDS. Fracture toughness; Fracture energy; Bovine femur bone; Experimental study.



Citation: Aliha, M.R.M., Ghazi, H., Ataei, F., Experimental fracture resistance study for cracked bovine femur bone samples, Frattura ed Integrità Strutturale, 50 (2019) 602-612.

Received: 09.05.2019

Accepted: 26.08.2019

Published: 01.10.2019

Copyright: (C) 2019 This is an open access article under the terms of the CC-BY 4.0, which permits unrestricted use, distribution, and reproduction in any medium, provided the original author and source are credited.

\section{INTRODUCTION}

one is a quasi-brittle and orthotropic material, which in practice can be subjected to different types of mechanical loads inside the body of human or animal with different rates ranging from static to dynamic or even impact loads. Thus these materials are usually vulnerable to failure and catastrophic fracture. Because of applied loads and stresses, 
the mechanism of failure and damage in bone materials often involves micro and macro cracking or sometimes other failure modes like delamination and etc. Accordingly, the common and general mechanical properties like tensile strength, elasticity modulus, flexural strength and hardness may not be sufficient to describe the resistance of bone against crack growth and other characteristic parameters such as fracture toughness $\left(K_{\mathrm{c}}\right)$ or fracture energy $\left(G_{\mathrm{f}}\right)$ must also be known for more accurate measurement of bone performance in vitro conditions against fracture. A number of research works have been published in the past for obtaining and investigating the fracture toughness and fracture energy of bone materials. $K_{\mathrm{c}}$ and $G_{\mathrm{f}}$ are the most fundamental parameters for explaining the resistance of material (like bone or other biomaterials) against crack growth and catastrophic failure. Norman et al. [1] tested the longitudinal fracture toughness of both human cortical bone and bovine cortical bone using the compact tension specimen. They obtained both $K_{\mathrm{Ic}}$ and $G_{\mathrm{Ic}}$ values for these two bone materials and derived an empirical relation between the fracture parameters (i.e. $K_{\mathrm{Ic}}$ and $G_{\mathrm{f}}$ ). Using a novel ring shape specimen, Barrero and Adams [2] obtained experimentally the mode I fracture toughness of rat cortical bone. The average value for the $K_{\text {Ic }}$ of rat bone was obtained about $0.55 \mathrm{MPa} \sqrt{\mathrm{m}}$ in their experiments. In another research paper, Behiri and Bonfield [3] investigated the effect of anisotropy and orientation effects on the fracture toughness of bovine cortical bone using a modified compact tension specimen. Lucksanasom et al. [4], investigated experimentally the effect of orientation and storage media on the fracture toughness of bovine femur and tibia bone. They tested a number of single edge notched beam bone samples taken from transverse and longitudinal directions and showed that the storing media (i.e. saline and alcohol) and also the direction of test sample have significant influence on the mode I fracture toughness of investigated bones. Similarly, Yan et al. [5] studied the effect of temperature on the fracture toughness of bovine femur and manatee rib using single edge $\mathrm{V}$ notched beam subjected to flexural four-point bend loading. They tested some bone samples at four different temperatures ranging from zero to $50{ }^{\circ} \mathrm{C}$ and observed that the fracture toughness decreases by increasing the temperature. In another research paper, Nalla and coworkers [6] studied tensile type fracture and R-curve behavior in human cortical bone. They showed that in vitro fracture toughness value rises linearly with crack extension. Mode I, mode II and mixed mode I/II fracture behavior of human cortical bone was also obtained experimentally by Zimmermann et al. [7] using edge cracked four-point bend loading. Based on their observation, both fracture onset and fracture initiation directions were differed in longitudinal and transverse directions mainly due the anisotropy and non-homogeneous nature of bone in comparison with most brittle and homogeneous materials. Using double cantilever beam (DCB) specimen, Morais et al. [8] determined the pure mode I fracture toughness of bone tissue. In other research works, the mode I, mode II and mixed mode I/II fracture toughness of human and bovine cortical bone have also been using different test specimens including DCB specimen for mode I testing [9], End Notched Flexure (ENF) specimen for mode II testing [10,11] and Single Leg Bending (SLB) test specimen for mixed mode I/II testing [12].

Several test specimens with different configurations have been employed and suggested in the past for conducting the fracture toughness experiments in different materials. Edge creaked rectangular beam subjected to three or four-point bend loading [13-23], compact test specimen subjected to tension loading [24-28], center cracked Brazilian disc specimen subjected to diametral compression[29-35], semi-circular specimen containing an edge crack and subjected to symmetric or asymmetric three-point bend loading [36-46], square plate containing center crack and subjected to far field pin loading [47]; edge cracked triangular specimen subjected to bend loading [48-50], center cracked ring specimen under compressive loading[51,52] and edge notch disc sample under three-point bend loading [53-61] are some of the frequently used test samples for obtaining mode I, mode II, mode III or mixed mode fracture toughness of brittle and quasi-brittle materials. Among the mentioned specimens, the rectangular edge cracked bend beam and edge cracked compact tension specimens are more favorite test specimens for manufacturing small size test samples which leads easy loading setup in biomaterials like bone or dentures. In this research, the fracture toughness and fracture energy of bovine femur bone is obtained experimentally using single edge notch bend (SENB) specimen. The effect of sample preparation location on the crack growth behavior of the tested bone is studied. It is also shown that a linear relation exists between the mode I fracture toughness and fracture energy of tested bone material.

\section{BONE FRACTURE TOUGHNESS TESTING}

wo fresh femur bones from a same bovine of unknown age were used. They were cut by means of band saw machine to obtain two cylindrical shape samples from each bone as shown in Fig 1. The bones were marked along a reference direction before cutting. A number of single edge notch beam specimens with size of $60 \mathrm{~mm} * 10 \mathrm{~mm} * 4 \mathrm{~mm}$ were cut and prepared from each cylindrical shape bone along the longitudinal direction. A vertical edge crack of length $5 \mathrm{~mm}$ was also introduced in the specimens using a very narrow saw blade. The crack length ratio $a / W$ in the manufactured sample was equal to 0.5 . Before testing the specimens were soaked in normal saline and wrapped in normal saline soaked gauge and 
were stored inside a freezer at $-8^{\circ} \mathrm{C}$ for $24 \mathrm{~h}$. The specimens were then loaded by a three-point bend fixture with bottom loading span of $40 \mathrm{~mm}$. Thus the loading span ratio was equal to $S / L=0.8$. The cross head speed of loading was fixed at rate of $1 \mathrm{~mm} / \mathrm{min}$ for all test samples. Figs. 2 and 3 show the schematic of test specimen and test setup used for fracture toughness testing of the bovine bone. Each specimen was loaded monotonically until the failure of specimen. The critical peak load $F_{\text {cr }}$ which was measured by the load cell of testing machine was used to calculate the mode I fracture toughness value, using the following equation:

$$
\mathrm{K}_{\mathrm{Ic}}=\frac{6 \mathrm{~F}_{\mathrm{cr}} \sqrt{\mathrm{a}}}{\mathrm{Bw}} \mathrm{f}\left(\frac{\mathrm{a}}{\mathrm{w}}\right)
$$

where the geometry factor $f(a / W)$ is function of crack length ratio $(a / W)$ and is written as:

$$
f(\mathrm{a} / \mathrm{w})=\frac{1.99-\frac{\mathrm{a}}{\mathrm{w}}\left(1-\frac{\mathrm{a}}{\mathrm{w}}\right)\left(2.15-\frac{3.93 \mathrm{a}}{\mathrm{w}}+2.7\left(\frac{\mathrm{a}}{\mathrm{w}}\right)^{2}\right)}{\left(1+\frac{2 \mathrm{a}}{\mathrm{w}}\right)\left(1-\frac{\mathrm{a}}{\mathrm{w}}\right)^{3 / 2}}
$$

The fracture energy $G_{\mathrm{f}}$ which is the representative of energy required for breaking the test specimen was also calculated from the area under the load-displacement curve of each test. In the next section, the experimental results of mode I fracture toughness $\left(K_{\mathrm{Ic}}\right)$ and mode I fracture energy $\left(G_{\mathrm{f}}\right)$ are presented.
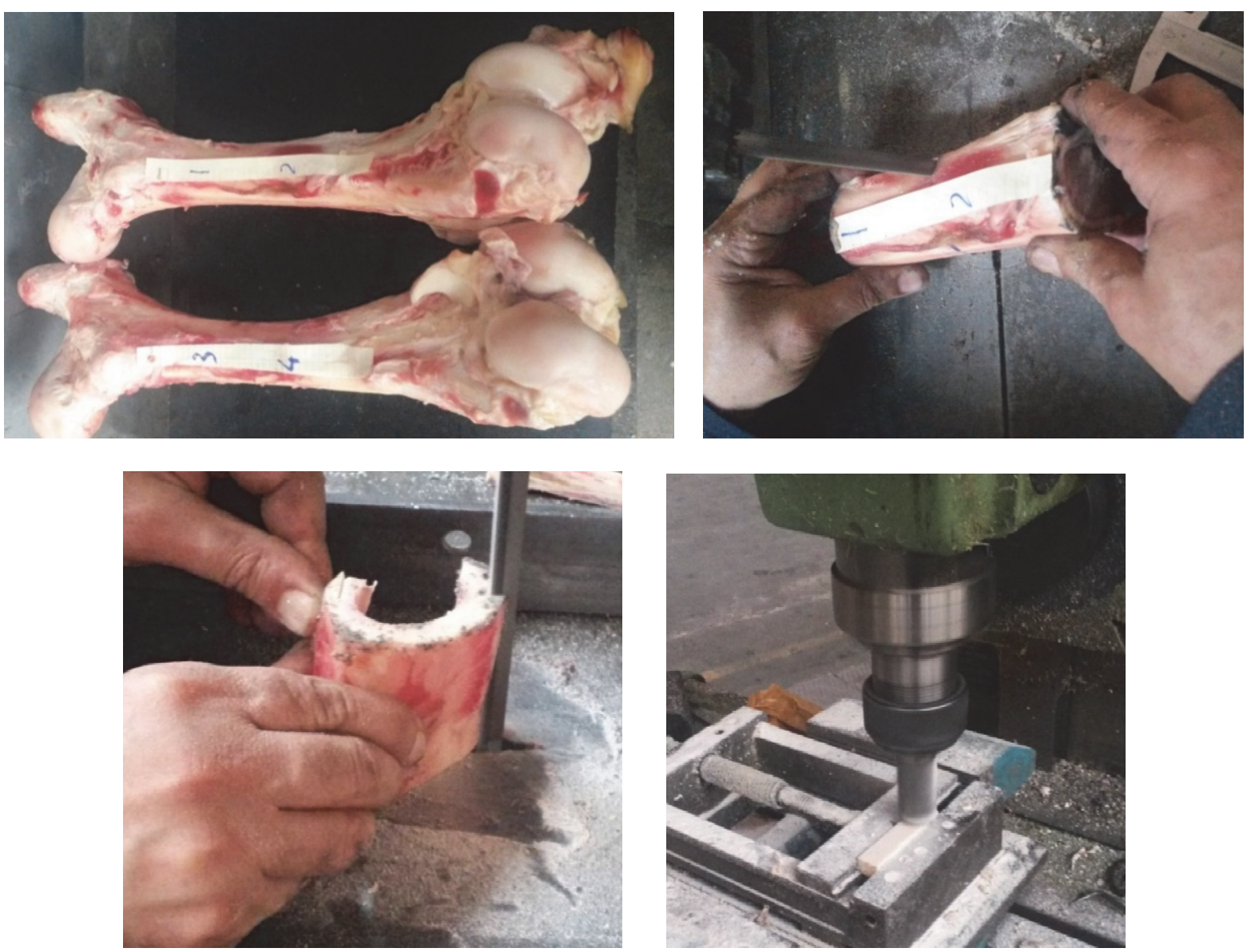

Figure 1: Test specimen preparation from the bovine femur in the shape of rectangular beam samples. 


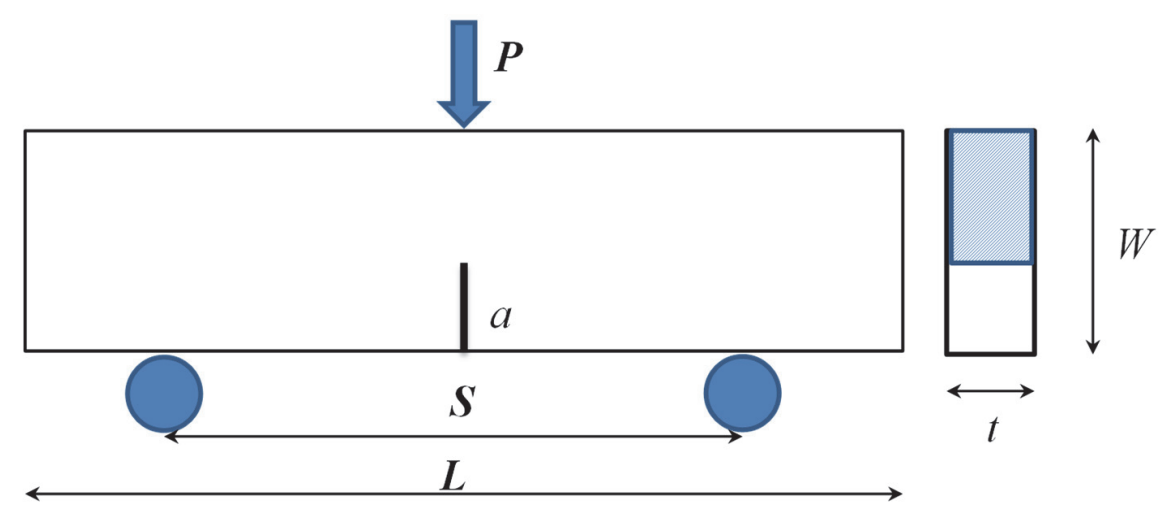

Figure 2: Geometry and loading conditions of the SENB specimen used for fracture experiments on bone material.

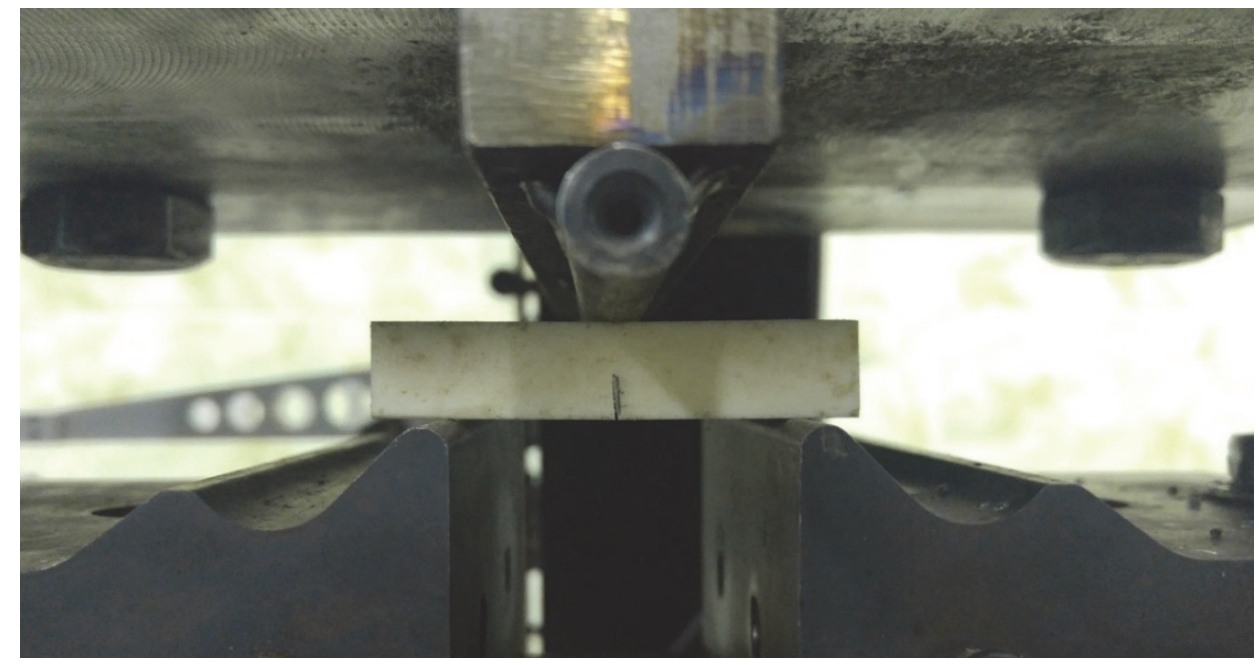

Figure 3: Test setup used for bone fracture toughness testing.

\title{
EXPERIMENTAL RESULTS AND DISCUSSION
}

\begin{abstract}
A typical load-displacement curve for one of the tested SENB specimens has been presented in Fig. 4, demonstrating linear elastic fracture behavior of tested bovine bone cut along the longitudinal direction. Thus the framework of LEFM was used to study the fracture behavior and obtain the fracture toughness value of tested bone samples. The calculated fracture results including the fracture toughness values and fracture energies for the tested bovine bone have been presented in Figs. 5 to 7. According to Figs. 5 and 7, a natural scatter is seen for fracture behavior of tested bone samples that such observation is inevitable for bone materials that have orthotropic nature in general. According to the fracture toughness results, the mode I fracture toughness value in the tested bone femur varies from minimum value of 4.9 $\mathrm{MPa} \sqrt{\mathrm{m}}_{\mathrm{m}}$ to maximum value of $10.4 \mathrm{MPa} \sqrt{\mathrm{m}}_{\mathrm{m}}$. Similarly, the lower and upper limits for the fracture energy value are $0.023 \mathrm{~J}$ and $0.113 \mathrm{~J}$, respectively. Variations of measured fracture toughness $\left(K_{\mathrm{Ic}}\right)$ for different SENB specimens given from different locations of left and right femurs (i.e. from top and bottom of bone or frontal or lateral side of the bone) are shown in Fig. 5. This Figure demonstrates that the average value of $K_{\text {Ic }}$ obtained from the left femur bone is nearly identical with the right femur of the same bovine. The average fracture toughness was obtained approximately equal to $6.8 \mathrm{MPa} \sqrt{\mathrm{m}}$ for the whole samples. Tab. 1 presents and compares the mode I fracture toughness value of bovine bone material reported by different researchers. It can be seen from Tab. 1 that the corresponding value of $K_{\mathrm{Ic}}$ determined in the current research is quite in good agreement with previous data obtained for the $K_{\mathrm{Ic}}$ of bovine bone. However, the fracture toughness $K_{\mathrm{Ic}}$ value depends noticeably on the orientation and location of sample extraction from the bone. Generally, it is seen from Fig. 6 that the lateral or side parts of the bone are approximately 20 to $30 \%$ weaker than the frontal part (i.e. along the marked line shown in Fig. 1) of the bovine femur bone.
\end{abstract}




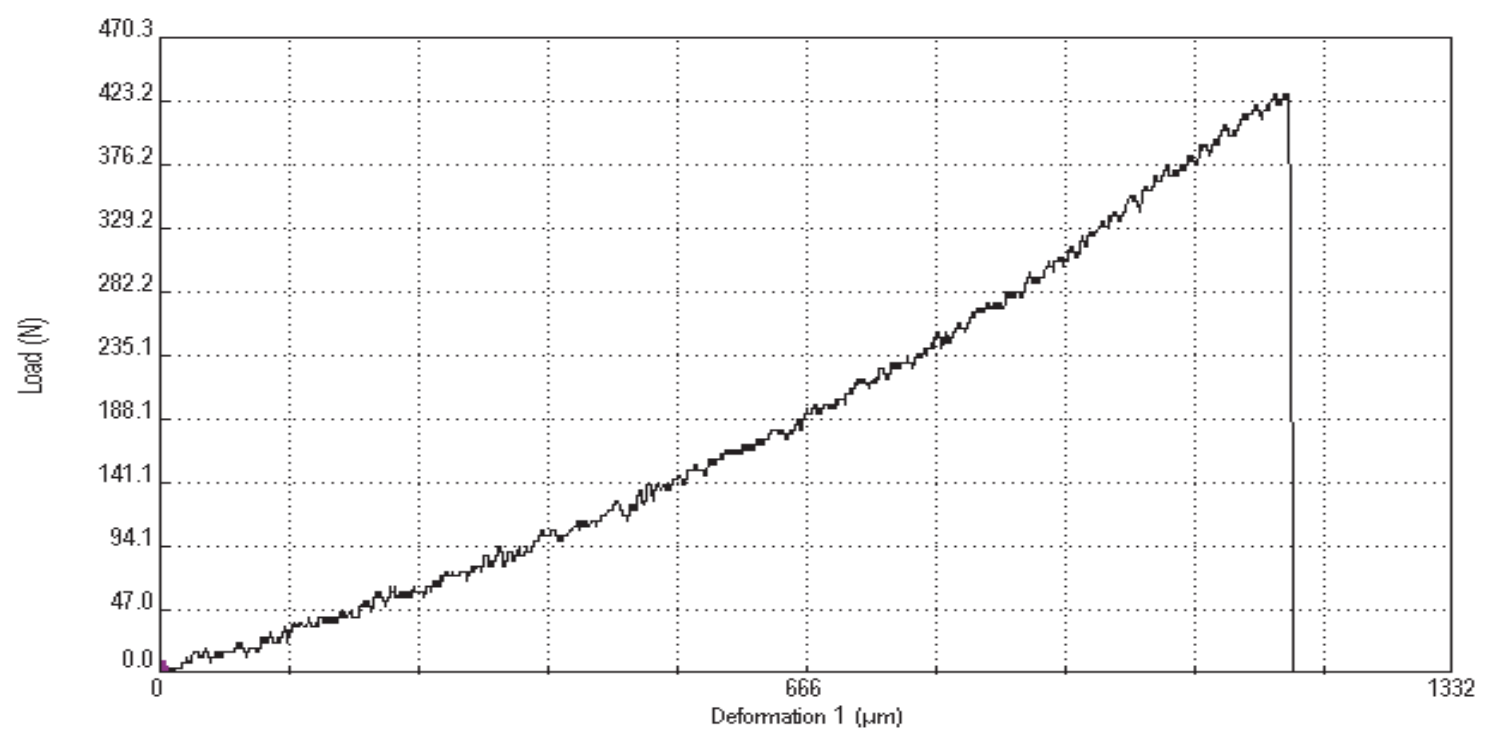

Figure 4: Typical load-displacement curve for one of the tested SENB specimens made of bovine femur.

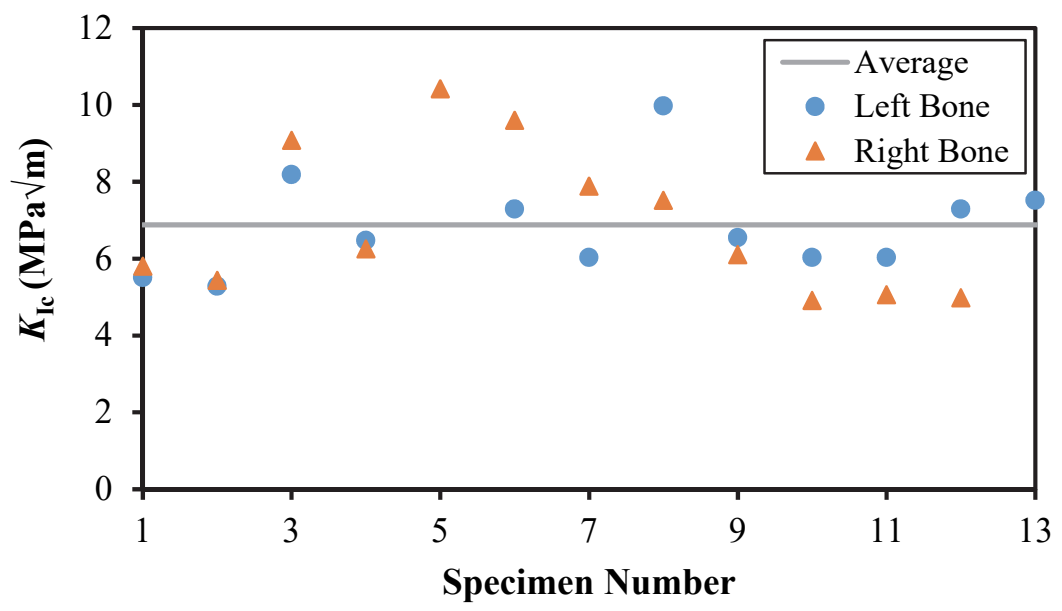

Figure 5: Variations of mode I fracture toughness for different SENB samples manufactured from the left and right bovine femur.

\begin{tabular}{|c|c|c|c|}
\hline Bone type & Test specimen & $\begin{array}{l}\text { Fracture toughness value } \\
\qquad(\mathrm{MPa} \sqrt{\mathrm{m}})\end{array}$ & Ref. \\
\hline Bovine femur & Chevron-notched bend beam & 5.8 & [66] \\
\hline bovine cortical bone & Compact tension & 6 & {$[67]$} \\
\hline Bovine femur & Four point bend beam & $4.3-7$ & {$[68]$} \\
\hline Bovine tibia & Compact tension & $2.8-6.3$ & [69] \\
\hline $\begin{array}{l}\text { Bovine } \\
\text { femur }\end{array}$ & Short rod Chevron-notched & 4.8 & [70] \\
\hline Bovine femur & Single-edge notched beam & 5.58 & [71] \\
\hline Bovine tibia & Compact tension & $4.93-12.64$ & [72] \\
\hline Bovine femur & Single-edge notched beam & $4-6$ & [73] \\
\hline Bovine femur & Compact tension & 4.3 & [74] \\
\hline Wet Bovine femur & Single-edge notched beam & 6.35 & {$[75]$} \\
\hline Fresh Bovine femur & Single-edge notched beam & 6.8 & Current research \\
\hline
\end{tabular}

Table 1: Comparison of bovine bone fracture toughness values reported in the literature. 


\section{$\square$ Front region of bone $\quad$ Side region of bone}

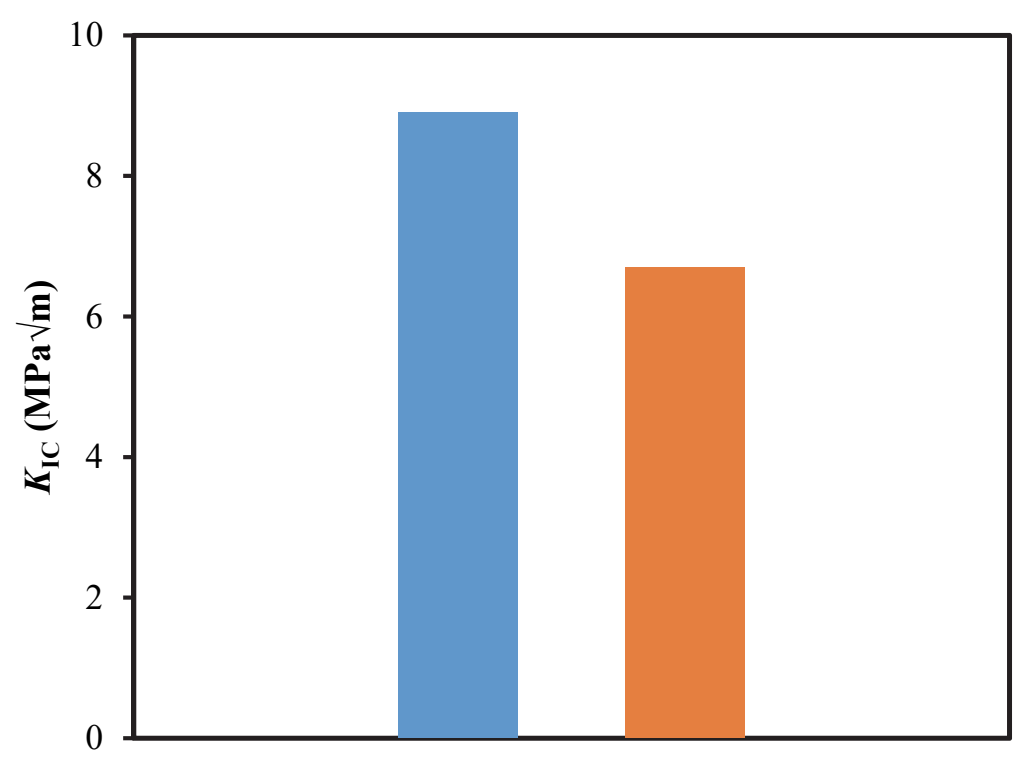

Figure 6: Comparison of $K_{\text {Ic }}$ values obtained for front and side regions of the tested bones.

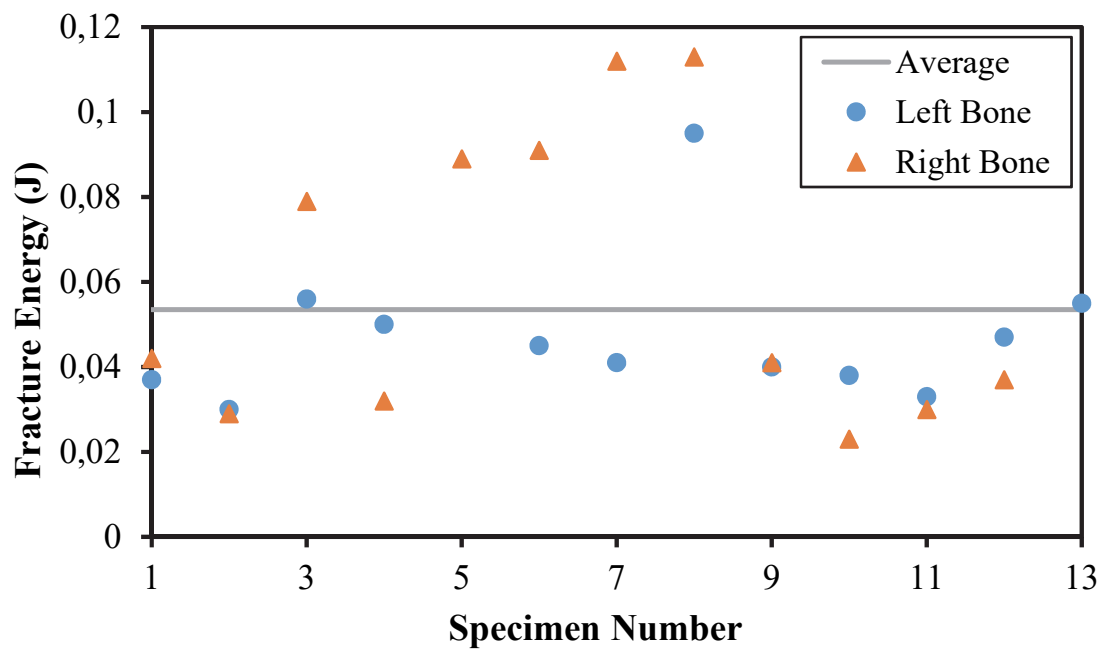

Figure 7: Variations of fracture energy $\left(G_{\mathrm{f}}\right)$ for different SENB samples manufactured from the left and right bovine femur.

Fig. 7 also presents the variations of fracture energy $\left(G_{\mathrm{f}}\right)$ for the tested SENB specimens made of bovine bone. The average of fracture energy was determined about $0.055 \mathrm{~J}$ for the tested SENB specimens made of bovine bone. However, the standard deviation and scatter of fracture energy results are greater than the fracture toughness data. Variations of $\left(K_{\mathrm{Ic}}\right)^{2}$ versus $G_{\mathrm{f}}$ for the whole experimental results of this research have been also plotted in Fig. 8. It is seen that there is a linear relationship between these two fracture parameters in the investigated bone that supports the well-known relation in the framework of linear elastic fracture mechanics (LEFM) between the stress intensity factor and fracture energy. According to the experimental findings of this research, the fracture index i.e. $\left(\frac{\mathrm{K}_{\mathrm{Ic}}}{\sqrt{\mathrm{G}_{f}}}\right)$ ratio for the tested bovine femur is approximately equal to 33. This index that is related to the well-known mechanical properties of the bone (such as elastic modulus, Poisson's ratio, tensile strength density and etc.) can be used for estimating the corresponding value of fracture toughness in terms of the fracture energy value and vice versa. The trajectory of fracture path for the whole samples given from 
different locations of bones was straight and along the initial crack with no significant curvature. A typical fracture surface (with magnification of 60x) observed for one of the bone samples has also been shown in Fig. 9. The microstructure of the investigated bone exhibits a rather smooth pattern that demonstrates dominantly tensile and brittle type of fracture for the tested SENB specimens made of bovine femur bone. Indeed, the fracture patterns of the tested bovine bone are very similar to cleavage fracture in brittle materials in which the micro cracks propagate through the weak paths of cement line leading a tensile type brittle fracture. In addition, despite many engineering and industrial materials that have continuum and homogenous structure, the micro structure of bone materials shown in Fig. 9 consists of different parts including osteons, vascular and volkmann canals and secondary osteons $[75,76]$ which results in non-continuum and non-homogenous micro structure for the bone as natural material. Due to random distribution of such parts inside the bone and also difference in the size and number of these particles (that some of them like vascular canals and secondary osteons act as stress concentrations or weak points), a significant and noticeable scatter in their fracture and cracking behavior might be inevitable and expected as shown via the several fracture experiments of this research for a same bovine femur bone material.

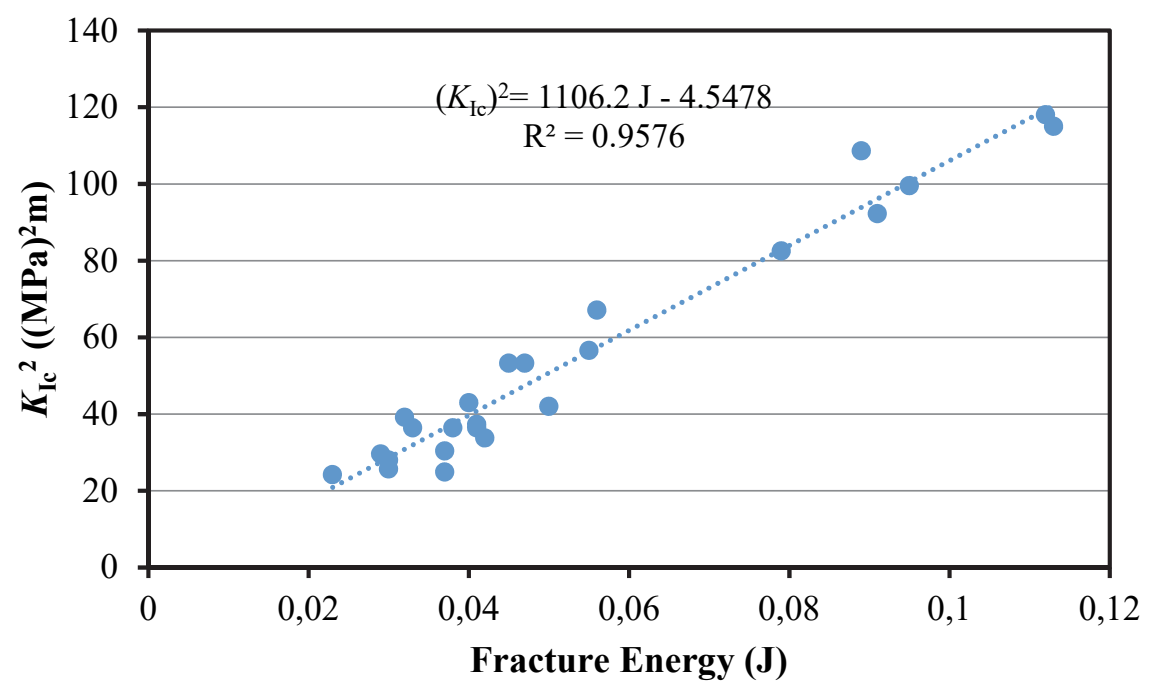

Figure 8: Relationship between the fracture toughness and fracture energy of tested bone samples.
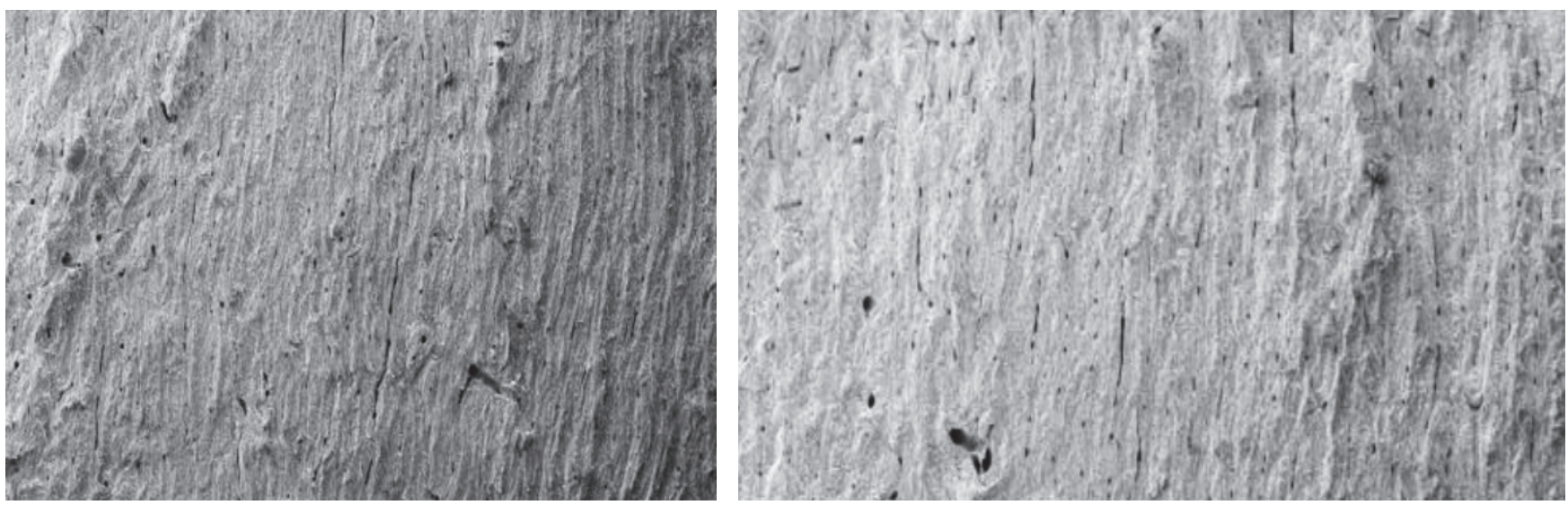

Figure 9: Typical fracture surface of tested SENB specimens under pure mode I loading condition.

\section{CONCLUSIONS}

- Fracture toughness $\left(K_{\mathrm{Ic}}\right)$ of two fresh femur bones of the same bovine was measured experimentally using single edge notch bend beam (SENB) specimen. 
- The fracture toughness of samples was dependent on the location of specimen cutting from the femur and the frontal part of the bone had stronger crack growth resistance in comparison with the other parts along the hoop direction.

- The fracture toughness results obtained from the left and right femur bone were nearly identical.

- The fracture energy $\left(G_{\mathrm{f}}\right)$ required for breaking and splitting the bone samples were also measured and it was found that there is a nearly linear relation between the fracture toughness $\left(K_{\text {Ic }}\right)$ and fracture energy $\left(G_{\mathrm{f}}\right)$ for the tested femur bone. Therefore, the fracture energy of tested bone can be estimated in terms of fracture toughness value and vice versa.

- The natural and noticeable scatter observed in the fracture behavior of tested bone (i.e. fracture toughness and fracture energy) is mainly attributed to randomly distribution of different parts (such as voids, canals and secondary osteons) existing in the micro-structure of bone material.

\section{REFERENCES}

[1] Norman, T. L., Vashishth, D., \& Burr, D. B. (1995). Fracture toughness of human bone under tension. Journal of biomechanics, 28(3), pp. 313-320. DOI: 10.1016/0021-9290(94)00069-G

[2] Barrero, M., \& Adams, D. J. (2004). A Fracture Toughness Test for Rat Cortical Bone (Doctoral dissertation, University of Connecticut).

[3] Behiri, J. C., \& Bonfield, W. (1989). Orientation dependence of the fracture mechanics of cortical bone. Journal of biomechanics, 22(8), pp. 863-867. DOI: 10.1016/0021-9290(89)90070-5

[4] Lucksanasombool, P., Higgs, W. A. J., Higgs, R. J. E. D., \& Swain, M. V. (2001). Fracture toughness of bovine bone: influence of orientation and storage media. Biomaterials, 22(23), pp. 3127-3132.

DOI: $10.1016 /$ S0142-9612(01)00062-X

[5] Yan, J., Clifton, K. B., Mecholsky, J. J., \& Gower, L. A. (2007). Effect of temperature on the fracture toughness of compact bone. Journal of biomechanics, 40(7), pp. 1641-1645. DOI: 10.1016/j.jbiomech.2006.07.011

[6] Nalla, R. K., Kruzic, J. J., Kinney, J. H., \& Ritchie, R. O. (2005). Mechanistic aspects of fracture and R-curve behavior in human cortical bone. Biomaterials, 26(2), pp. 217-231. DOI: 10.1016/j.biomaterials.2004.02.017

[7] Zimmermann, E. A., Launey, M. E., Barth, H. D., \& Ritchie, R. O. (2009). Mixed-mode fracture of human cortical bone. Biomaterials, 30(29), pp. 5877-5884. DOI: 10.1016/j.biomaterials.2009.06.017

[8] Morais, J. J. L., De Moura, M. F. S. F., Pereira, F. A. M., Xavier, J., Dourado, N., Dias, M. I. R., \& Azevedo, J. M. T. D. (2010). The double cantilever beam test applied to mode I fracture characterization of cortical bone tissue. Journal of the Mechanical Behavior of Biomedical Materials, 3(6), pp. 446-453. DOI: 10.1016/j.jmbbm.2010.04.001

[9] Pereira, F. A. M., De Moura, M. F. S. F., Dourado, N., Morais, J. J. L., Xavier, J., \& Dias, M. I. R. (2017). Direct and inverse methods applied to the determination of mode I cohesive law of bovine cortical bone using the DCB test. International Journal of Solids and Structures, 128, pp. 210-220. DOI: 10.1016/j.ijsolstr.2017.08.028

[10] Pereira, F. A. M., de Moura, M. F. S. F., Dourado, N., Morais, J. J. L., Xavier, J., \& Dias, M. I. R. (2018). Determination of mode II cohesive law of bovine cortical bone using direct and inverse methods. International Journal of Mechanical Sciences, 138, pp. 448-456. DOI: 10.1016/j.ijmecsci.2018.02.009

[11] Silva, F. G. A., de Moura, M. F. S. F., Dourado, N., Xavier, J., Pereira, F. A. M., Morais, J. J. L., ... \& Judas, F. M. (2017). Fracture characterization of human cortical bone under mode II loading using the end-notched flexure test. Medical \& biological engineering \& computing, 55(8), pp. 1249-1260. DOI: 10.1007/s11517-016-1586-6,

[12] Silva, F. G. A., de Moura, M. F. S. F., Dourado, N., Xavier, J., Pereira, F. A. M., Morais, J. J. L., \& Dias, M. I. R. (2016). Mixed-mode I+ II fracture characterization of human cortical bone using the Single Leg Bending test. Journal of the mechanical behavior of biomedical materials, 54, pp. 72-81. DOI: 10.1016/j.jmbbm.2015.09.004

[13] Zimmermann, E. A., Launey, M. E., \& Ritchie, R. O. (2010). The significance of crack-resistance curves to the mixedmode fracture toughness of human cortical bone. Biomaterials, 31(20), pp. 5297-5305.

DOI: $10.1016 /$ j.biomaterials.2010.03.056

[14] Margevicius, R. W., Riedle, J., \& Gumbsch, P. (1999). Fracture toughness of polycrystalline tungsten under mode I and mixed mode I/II loading. Materials Science and Engineering: A, 270(2), pp. 197-209.

DOI: 10.1016/S0921-5093(99)00252-X

[15] Suresh, S., Shih, C. F., Morrone, A., \& O'Dowd, N. P. (1990). Mixed-mode fracture toughness of ceramic materials. Journal of the American Ceramic Society, 73(5), pp. 1257-1267. DOI: 10.1111/j.1151-2916.1990.tb05189.x 
[16] Bechtle, S., Habelitz, S., Klocke, A., Fett, T., \& Schneider, G. A. (2010). The fracture behaviour of dental enamel. Biomaterials, 31(2), pp. 375-384. DOI: 10.1016/j.biomaterials.2009.09.050

[17] Maccagno, T. M., \& Knott, J. F. (1989). The fracture behaviour of PMMA in mixed modes I and II. Engineering Fracture Mechanics, 34(1), pp. 65-86. DOI: 10.1016/0013-7944(89)90243-9

[18] Fakhri, M., Amoosoltani, E., \& Aliha, M. R. M. (2017). Crack behavior analysis of roller compacted concrete mixtures containing reclaimed asphalt pavement and crumb rubber. Engineering Fracture Mechanics, 180, pp. 43-59. DOI: 10.1016/j.engfracmech.2017.05.011

[19] Razavi, S. M. J., Aliha, M. R. M., \& Berto, F. (2018). Application of an average strain energy density criterion to obtain the mixed mode fracture load of granite rock tested with the cracked asymmetric four-point bend specimens. Theoretical and Applied Fracture Mechanics. 97, pp. 419-425. DOI: 10.1016/j.tafmec.2017.07.004

[20] Abdollahi, A., \& Arias, I. (2011). Phase-field simulation of anisotropic crack propagation in ferroelectric single crystals: effect of microstructure on the fracture process. Modelling and Simulation in Materials Science and Engineering, 19(7), 074010. DOI: $10.1088 / 0965-0393 / 19 / 7 / 074010$

[21] Xeidakis, G. S., Samaras, I. S., Zacharopoulos, D. A., \& Papakaliatakis, G. E. (1996). Crack growth in a mixed-mode loading on marble beams under three point bending. International journal of fracture, 79(2), pp. 197-208. DOI: $10.1007 /$ BF00032936.

[22] Gómez, F. J., Elices, M., Berto, F., \& Lazzarin, P. (2009). Fracture of V-notched specimens under mixed mode (I+ II) loading in brittle materials. International journal of fracture, 159(2), 121. DOI: 10.1007/s10704-009-9387-7.

[23] Lazzarin, P., Berto, F., Elices, M., \& Gómez, J. (2009). Brittle failures from U-and V-notches in mode I and mixed, I+ II, mode: a synthesis based on the strain energy density averaged on finite-size volumes. Fatigue \& Fracture of Engineering Materials \& Structures, 32(8), pp. 671-684. DOI: 10.1111/j.1460-2695.2009.01373.x

[24] Park, S., \& Sun, C. T. (1995). Fracture criteria for piezoelectric ceramics. Journal of the American Ceramic Society, 78(6), pp. 1475-1480. DOI: 10.1111/j.1151-2916.1995.tb08840.x

[25] Davenport, J. C. W., \& Smith, D. J. (1993). A study of superimposed fracture modes I, II and III on PMMA. Fatigue \& Fracture of Engineering Materials \& Structures, 16(10), pp. 1125-1133. DOI: 10.1111/j.1460-695.1993.tb00082.x

[26] Al-Haidary, J. T., Wahab, A. A., \& Salam, E. A. (2006). Fatigue crack propagation in austenitic stainless steel weldments. Metallurgical and Materials Transactions A, 37(11), pp. 3205-3214. DOI: 10.1007/BF02586155

[27] Azar, H. F., Choupani, N., Afshin, H., \& Moghadam, R. H. (2015). Effect of mineral admixtures on the mixed-mode (I/II) fracture characterization of cement mortar: CTS, CSTBD and SCB specimens. Engineering Fracture Mechanics, 134, pp. 20-34. DOI: $10.1016 /$ j.engfracmech.2014.12.008

[28] Jamali, J., Fan, Y., \& Wood, J. T. (2015). The mixed-mode fracture behavior of epoxy by the compact tension shear test. International Journal of Adhesion and Adhesives, 63, pp. 79-86. DOI: 10.1016/j.ijadhadh.2015.08.006

[29] Abd-Elhady, A. (2013). Mixed mode I/II stress intensity factors through the thickness of disc type specimens. Engineering Solid Mechanics, 1(4), pp. 119-128. doi: 10.5267/j.esm.2013.10.001

[30] Mirsayar, M. M., Berto, F., Aliha, M. R. M., \& Park, P. (2016). Strain-based criteria for mixed-mode fracture of polycrystalline graphite. Engineering Fracture Mechanics, 156, pp. 114-123. DOI: 10.1016/j.engfracmech.2016.02.011

[31] Awaji, H., \& Sato, S. (1978). Combined mode fracture toughness measurement by the disk test. Journal of Engineering Materials and Technology, 100(2), pp. 175-182. doi:10.1115/1.3443468.

[32] Chang, S. H., Lee, C. I., \& Jeon, S. (2002). Measurement of rock fracture toughness under modes I and II and mixedmode conditions by using disc-type specimens. Engineering geology, 66(1-2), pp. 79-97. DOI: 10.1016/S0013-7952(02)00033-9

[33] Aliha, M. R. M., Ayatollahi, M. R., \& Akbardoost, J. (2012). Typical upper bound-lower bound mixed mode fracture resistance envelopes for rock material. Rock mechanics and rock engineering, 45(1), pp. 65-74. DOI: $10.1007 / \mathrm{s} 00603-011-0167-0$.

[34] Aliha, M. R. M., Mahdavi, E., \& Ayatollahi, M. R. (2017). The influence of specimen type on tensile fracture toughness of rock materials. Pure and Applied Geophysics, 174(3), pp. 1237-1253. DOI: 10.1007/s00024-016-1458-x

[35] Ayatollahi, M. R., \& Aliha, M. R. M. (2008). Mixed mode fracture analysis of polycrystalline graphite-a modified MTS criterion. Carbon, 46(10), pp. 1302-1308. DOI: 10.1016/j.carbon.2008.05.008

[36] Ayatollahi, M. R., Aliha, M. R. M., \& Hassani, M. M. (2006). Mixed mode brittle fracture in PMMA—an experimental study using SCB specimens. Materials Science and Engineering: A, 417(1-2), pp. 348-356.

DOI: 10.1016/j.msea.2005.11.002

[37] Ayatollahi, M. R., Aliha, M. R. M., \& Saghafi, H. (2011). An improved semi-circular bend specimen for investigating mixed mode brittle fracture. Engineering Fracture Mechanics, 78(1), pp. 110-123.

DOI: 10.1016/j.engfracmech.2010.10.001 
[38] Akbardoost, J., Ayatollahi, M. R., Aliha, M. R. M., Pavier, M. J., \& Smith, D. J. (2014). Size-dependent fracture behavior of Guiting limestone under mixed mode loading. International Journal of Rock Mechanics and Mining Sciences, 71, pp. 369-380. DOI: 10.1016/j.ijrmms.2014.07.019

[39] Aliha, M. R. M., Ayatollahi, M. R., Smith, D. J., \& Pavier, M. J. (2010). Geometry and size effects on fracture trajectory in a limestone rock under mixed mode loading. Engineering Fracture Mechanics, 77(11), pp. 2200-2212. DOI: $10.1016 /$ j.engfracmech.2010.03.009

[40] Aliha, M. M., Behbahani, H., Fazaeli, H., \& Rezaifar, M. H. (2014). Study of characteristic specification on mixed mode fracture toughness of asphalt mixtures. Construction and Building Materials, 54, pp. 623-635. DOI: 10.1016/j.conbuildmat.2013.12.097

[41] Aliha, M. R. M., Fazaeli, H., Aghajani, S., \& Nejad, F. M. (2015). Effect of temperature and air void on mixed mode fracture toughness of modified asphalt mixtures. Construction and Building Materials, 95, pp. 545-555. DOI: 10.1016/j.conbuildmat.2015.07.165

[42] Aliha, M. R. M., Bahmani, A., \& Akhondi, S. (2016). Mixed mode fracture toughness testing of PMMA with different three-point bend type specimens. European Journal of Mechanics-A/Solids, 58, pp. 148-162.

DOI: $10.1016 /$ j.euromechsol.2016.01.012

[43] Ameri, M., Nowbakht, S., Molayem, M., \& Aliha, M. R. M. (2016). Investigation of fatigue and fracture properties of asphalt mixtures modified with carbon nanotubes. Fatigue \& fracture of engineering materials \& structures, 39(7), pp. 896-906. DOI: $10.1111 /$ ffe. 12408

[44] Lim, I. L., Johnston, I. W., Choi, S. K., \& Boland, J. N. (1994). Fracture testing of a soft rock with semi-circular specimens under three-point bending. Part 2-mixed-mode. In International journal of rock mechanics and mining sciences \& geomechanics abstracts. 31,(3), pp. 199-212. DOI: 10.1016/0148-9062(94)90464-2

[45] Marsavina, L., Constantinescu, D. M., Linul, E., Apostol, D. A., Voiconi, T., \& Sadowski, T. (2014). Refinements on fracture toughness of PUR foams. Engineering Fracture Mechanics, 129, pp. 54-66. DOI: $10.1016 /$ j.engfracmech.2013.12.006

[46] Negru, R., Marsavina, L., Filipescu, H., \& Pasca, N. (2013). Investigation of mixed mode I/II brittle fracture using ASCB specimen. International Journal of Fracture, 181(1), pp. 155-161. DOI: 10.1007/s10704-013-9830-7.

[47] Ayatollahi, M. R., \& Aliha, M. R. M. (2009). Analysis of a new specimen for mixed mode fracture tests on brittle materials. Engineering Fracture Mechanics, 76(11), pp. 1563-1573. DOI: 10.1016/j.engfracmech.2009.02.016

[48] Mirsayar, M. M., Razmi, A., Aliha, M. R. M., \& Berto, F. (2018). EMTSN criterion for evaluating mixed mode I/II crack propagation in rock materials. Engineering Fracture Mechanics. 190, pp. 186-197.

DOI: $10.1016 /$ j.engfracmech.2017.12.014

[49] Aliha, M. R. M., Hosseinpour, G. R., \& Ayatollahi, M. R. (2013). Application of cracked triangular specimen subjected to three-point bending for investigating fracture behavior of rock materials. Rock mechanics and rock engineering, 46(5), 1023-1034. DOI: 10.1007/s00603-012-0325-z

[50] Aliha, M. R. M., Bahmani, A., \& Akhondi, S. (2016). Mixed mode fracture toughness testing of PMMA with different three-point bend type specimens. European Journal of Mechanics-A/Solids, 58, pp. 148-162.

DOI: 10.1016/j.euromechsol.2016.01.012

[51] Aliha, M. R. M., Pakzad, R., \& Ayatollahi, M. R. (2013). Numerical analyses of a cracked straight-through flattened Brazilian disk specimen under mixed-mode loading. Journal of Engineering Mechanics, 140(1), pp. $219-224$. DOI: 10.1061/(ASCE)EM.1943-7889.0000651

[52] Dehghany, M., Saeidi Googarchin, H., \& Aliha, M. R. M. (2017). The role of first non-singular stress terms in mixed mode brittle fracture of V-notched components: an experimental study. Fatigue \& Fracture of Engineering Materials \& Structures, 40(4), pp. 623-641. DOI: 10.1111/ffe.12539

[53] Aliha, M. R. M., Bahmani, A., \& Akhondi, S. (2015). Determination of mode III fracture toughness for different materials using a new designed test configuration. Materials \& Design, 86, pp. 863-871.

DOI: $10.1016 /$ j.matdes.2015.08.033

[54] Aliha, M. R. M., Bahmani, A., \& Akhondi, S. (2015). Numerical analysis of a new mixed mode I/III fracture test specimen. Engineering Fracture Mechanics, 134, pp. 95-110. DOI: 10.1016/j.engfracmech.2014.12.010

[55] Aliha, M. R. M., Bahmani, A., \& Akhondi, S. (2016). A novel test specimen for investigating the mixed mode I+ III fracture toughness of hot mix asphalt composites-Experimental and theoretical study. International Journal of Solids and Structures, 90, pp. 167-177. DOI: 10.1016/j.ijsolstr.2016.03.018

[56] Aliha, M. R. M., Berto, F., Bahmani, A., Akhondi, S., \& Barnoush, A. (2016). Fracture assessment of polymethyl methacrylate using sharp notched disc bend specimens under mixed mode I+ III loading. Physical Mesomechanics, 19(4), pp. 355-364. DOI: 10.1134/S1029959916040020 
[57] Aliha, M. R. M., Sarbijan, M. J., \& Bahmani, A. (2017). Fracture toughness determination of modified HMA mixtures with two novel disc shape configurations. Construction and Building Materials, 155, pp. 789-799.

DOI: 10.1016/j.conbuildmat.2017.08.093

[58] Aliha, M. R. M., Linul, E., Bahmani, A., \& Marsavina, L. (2018). Experimental and theoretical fracture toughness investigation of PUR foams under mixed mode I+ III loading. Polymer Testing, 67, pp. 75-83.

DOI: 10.1016/j.polymertesting.2018.02.015

[59] Aliha, M. R. M., Berto, F., Mousavi, A., \& Razavi, S. M. J. (2017). On the applicability of ASED criterion for predicting mixed mode I+ II fracture toughness results of a rock material. Theoretical and Applied Fracture Mechanics, 92, pp. 198-204. DOI: 10.1016/j.tafmec.2017.07.022

[60] Bahmani, A., Aliha, M. R. M., \& Berto, F. (2017). Investigation of fracture toughness for a polycrystalline graphite under combined tensile-tear deformation. Theoretical and Applied Fracture Mechanics, 90, pp. 53-64.

DOI: $10.1016 /$ j.tafmec.2017.02.011

[61] Aliha, M. R. M., \& Bahmani, A. (2017). Rock fracture toughness study under mixed mode I/III loading. Rock Mechanics and Rock Engineering, 50(7), 1739-1751. DOI: 10.1007/s00603-017-1201-7

[62] Ritchie, R. O., Kinney, J. H., Kruzic, J. J., \& Nalla, R. K. (2005). A fracture mechanics and mechanistic approach to the failure of cortical bone. Fatigue \& Fracture of Engineering Materials \& Structures, 28(4), 345-371. DOI: $10.1111 / j .1460-2695.2005 .00878 . x$

[63] Ritchie, R. O., Kinney, J. H., Kruzic, J. J., \& Nalla, R. K. (2006). Cortical bone fracture. Wiley encyclopedia of biomedical engineering.

[64] Lucksanasombool, P., Higgs, W. A. J., Higgs, R., \& Swain, M. V. (2001). Effect of temperature on the fracture toughness of compact bone. Journal of Biomaterials, 22(23), pp. 3127-3132.

[65] Nalla, R. K., Kinney, J. H., \& Ritchie, R. O. (2003). Mechanistic fracture criteria for the failure of human cortical bone. Nature materials, 2(3), 164-168. DOI: 10.1038/nmat832

[66] Yan, J., Clifton, K. B., Mecholsky Jr, J. J., \& Reep, R. L. (2006). Fracture toughness of manatee rib and bovine femur using a chevron-notched beam test. Journal of biomechanics, 39(6), pp. 1066-1074.

DOI: $10.1016 /$ j.jbiomech.2005.02.016

[67] Feng, Z., Rho, J., Han, S., \& Ziv, I. (2000). Orientation and loading condition dependence of fracture toughness in cortical bone. Materials Science and Engineering: C, 11(1), pp. 41-46. DOI: 10.1016/S0928-4931(00)00142-9

[68] Yan, J. (2005). Elastic-plastic fracture mechanics of compact bone. University of Florida.

[69] Behiri, J. C., \& Bonfield, W. (1984). Fracture mechanics of bone- the effects of density, specimen thickness and crack velocity on longitudinal fracture. Journal of biomechanics, 17(1), pp. 25-34. DOI: 10.1016/0021-9290(84)90076-9

[70] De Santis, R., Anderson, P., Tanner, K. E., Ambrosio, L., Nicolais, L., Bonfield, W., \& Davis, G. R. (2000). Bone fracture analysis on the short rod chevron-notch specimens using the X-ray computer micro-tomography. Journal of Materials Science: Materials in Medicine, 11(10), pp. 629-636. DOI: 10.1023/A:1008909830421

[71] Melvin, J. W. (1993). Fracture mechanics of bone. Journal of biomechanical engineering, 115(4B), pp. 549-554. DOI: $10.1115 / 1.2895538$

[72] Norman, T. L., Vashishth, D., \& Burr, D. B. (1992). Effect of groove on bone fracture toughness. Journal of biomechanics, 25(12), pp. 1489-1492. DOI: 10.1016/0021-9290(92)90061-5

[73] Adharapurapu, R. R., Jiang, F., \& Vecchio, K. S. (2006). Dynamic fracture of bovine bone. Materials Science and Engineering: C, 26(8), pp. 1325-1332. DOI: 10.1016/j.msec.2005.08.008.

[74] Bonfield, W., Grynpas, M. D., \& Young, R. J. (1978). Crack velocity and the fracture of bone. Journal of Biomechanics, 11(10-12), pp. 473-479. DOI: 10.1016/0021-9290(78)90058-1

[75] Chen, P. Y., Sheppard, F. A., Curiel, J. M., \& McKittrick, J. (2008). Fracture Mechanisms of Bone: A Comparative Study between Antler and Bovine Femur. MRS Online Proceedings Library Archive, DOI: 1132. 10.1557/PROC-1132-Z01-04.

[76] Aliha, M. R. M., Bagherifard, S., Akhondi, S., Mousavi, S. S., Mousavi, A., \& Parsania, H. (2018). Fracture and microstructural study of bovine bone under mixed mode I/II loading. Procedia Structural Integrity, 13, pp. 1488-1493. DOI: $10.1016 /$ j.prostr.2018.12.306. 